\title{
PEMBINAAN KEAGAMAAN BAGI SANTRI WARIA DI PESANTREN AL-FATAH KOTAGEDE YOGYAKARTA
}

\author{
Yulinda Nurul Listyani, * \\ Aceng Kosasih, Wawan Hermawan \\ Program Studi Ilmu Pendidikan Agama Islam, \\ Fakultas Pendidikan Ilmu Pengetahuan Sosial, Universitas Pendidikan Indonesia \\ *Email: yulindanurul02@gmail.com
}

\begin{abstract}
ABSTRAK
Penelitian ini dilatarbelakangi oleh adanya sebagian individu yang merasakan ketidaksamaan dalam pemberian sikap masyarakat terhadap dirinya sendiri. Inilah yang terjadi pada waria. Fenomena kaum waria merupakan suatu paparan nyata yang tidak dapat ditolak eksistensinya di masyarakat. Dewasa ini, perilaku waria seringkali menyimpang dari ajaran agama Islam, oleh karena itu waria membutuhkan pembinaan keagamaan agar waria meninggalkan perilaku buruk yang selama ini ditampakkan. Pembinaan keagamaan di pesantren bagi santri waria hanya ada satu di Indonesia yaitu, Pesantren Al-Fatah Kotagede Yogyakarta. Pesantren Al-Fatah membina banyak waria di dalamnya agar menjadi manusia lebih baik dan terarah. Keberlangsungan pembinaan keagamaan bagi waria ini menarik untuk diteliti. Pada penelitian ini yang diteliti adalah pembinaan keagamaan yang terdapat di pesantren tersebut. Oleh karena itu, pokok permasalahan dari penelitian ini yaitu tentang bagaimana pembinaan keagamaan bagi santri waria di Pesantren Al-Fatah Kotagede Yogyakarta. Adapun tujuan pokoknya yakni untuk mengetahui lebih dalam proses pembinaan keagamaan di Pesantren Al-Fatah Kotagede Yogyakarta. Penelitian ini menggunakan metode studi kasus dengan pendekatan kualitatif. Kemudian, pengumpulan data dilakukan melalui wawancara, observasi, dan studi dokumen. Analisis data pada penelitian ini yaitu reduksi data, penyajian data, penarikan kesimpulan/verifikasi. Hasil temuan dari penelitian di pesantren ini yaitu perencanaan yang terdapat di Pesantren Al-Fatah dilakukan dengan cara berdiskusi antara pengurus dan para ustāż. Kegiatan yang dilaksanakan di Pesantren Al-Fatah terbagi menjadi tiga yaitu kegiatan mingguan, kegiatan bulanan, dan kegiatan tahunan. Pembinaan keagamaan yang telah dilaksanakan secara rutin ini telah berhasil membuat perubahan dalam diri waria dari segi ibadah, tingkah laku dan profesi, adanya pesantren waria tersebut memberikan sumbangsih kepada masyarakat.
\end{abstract}

Kata Kunci: Pembinaan Keagamaan; Pesantren Waria. 


\section{PENDAHULUAN}

Pondok pesantren berarti suatu pendidikan agama Islam yang tumbuh serta diakui masyarakat sekitar, dengan sistem asrama (komplek) di mana santrisantri menerima pendidikan agama melalui sistem pengajian atau madrasah yang sepenuhnya berada di bawah kedaulatan dari leadership seorang atau beberapa orang kiai dengan ciri-ciri khas yang bersifat karismatik serta independen dalam segala hal. Sedangkan menurut buku Pesantren Dari Transformasi Metodologi Menuju Demokratis Institusi, pesantren didefinisikan sebagai suatu tempat pendidikan dan pengajaran yang menekankan pelajaran agama Islam dan didukung asrama sebagai tempat tinggal santri yang bersifat permanen (Qomar, 2010, hal. 2).

Tersebarnya pesantren di seluruh penjuru kota, berdiri pula pesantren yang khusus menangani waria yang terletak di kota Yogyakarta. Berbicara mengenai waria, dewasa ini banyak masalah-masalah islam kontemporer yang disebabkan beberapa faktor, salah satunya adalah faktor sosial yang mana faktor ini biasanya diperbincangkan dan menjadi berita terhangat dalam kehidupan bermasyarakat. Ada sebagian individu yang merasakan adanya ketidaksamaan dalam pemberian sikap masyarakat terhadap dirinya sendiri. Inilah yang terjadi pada waria. Mereka yang memiliki dan melakukan hal itu merasa tersudutkan karena masyarakat menganggap tindakantindakan yang dilakukan menurut asumsi mereka telah melanggar(Jevuska, 2012).

Berdasarkan

American

Psychologist

Assossiation

(APA)Dictionary, waria memiliki atau berhubungan dengan identitas gender yang berbeda dari kultural peran gender yang ditentukan dan jenis kelamin secara biologikal. Tingkatan waria juga berkaitan dan meliputi transeksual, beberapa bentuk lainnya adalah transvestisme dan interseksual (Stavia, 2013).
Gejala kewariaan yang selama ini dianggap sebagai gejala abnormalitas seksual tentunya tidak dapat dipisahkan dari komponen-komponen kehidupan seseorang yang tampak semakin rumit dan sulit dicari garis tegasnya. Beberapa ahli berpandangan bahwa keadaan abnormalitas seseorang, apapun bentuknya tidak dapat dipisahkan dari proses perkembangan manusia, sejak berada dalam kandungan hingga ia berada di alam kehidupan nyata. Oleh karena itu, analisis terhadap gejala kewariaan tidak dapat dilepaskan begitu saja dari konsep keilmuan mengenai perilaku manusia dan pendekatan-pendekatan keabnormalannya. Selain itu, sebagai manusia yang memiliki ketidakjelasan kelamin, seorang waria tentu juga dihadapkan kepada hukumhukum, baik tertulis maupun tidak tertulis yang menempatkan seorang waria pada hak dan kewajibannya sebagai makhluk sosial dan individu serta makhluk religius.

Adanya hak untuk mendapatkan ibadah yang sama dengan masyarakat pada umumnya mendorong munculnya suatu gebrakan. Seperti yang terjadi di Celenan, Jagalan, Banguntapan, Bantul, Yogyakarta yang berdiri sebuah pesantren khusus waria. Hal tersebut terkesan menjadi suatu keanehan, mengingat suatu pesantren diidentikan untuk manusia normal secara fisik dan psikologis. Latar belakang dari penelitian ini karena menyimpangnya perilaku waria dari ajaran agama Islam, oleh karena itu waria membutuhkan pembinaan keagamaan agar waria meninggalkan perilaku buruk yang selama ini ditampakkan kepada masyarakat luas. Pembinaan keagamaan di pesantren bagi santri waria telah ada dan hanya satusatunya di Indonesia.

Pesantren Al-Fatahmenangani banyak waria di dalamnya agar menjadi manusia lebih baik dan terarah.

Dalam agama Islam, mengganti jenis kelamin merupakan suatu larangan bagi pemeluknya. Bahkan hal tersebut 
ditegaskan dalam hadīs riwayat Bukhārī(dalam Nadia, 2005, hal. vi) yang menyatakan bahwa Rasūl Allāh melaknat seorang laki-laki yang menyerupai perempuan dan perempuan yang menyerupai laki-laki. Namun, menjadi fenomena yang "luar biasa" ketika orang yang secara jenis kelamin tidak sesuai dengan tuntunan agama tetapi mampu mendirikan suatu pondok pesantren dengan berlandaskan agama dan bahkan eksis di tengah masyarakat.

Dalam Pesantren Waria Al-Fatah juga menjadi hal menarik untuk melihat keagamaan santri yang seluruhnya merupakan waria. Selama ini waria yang sering terlihat di jalanan dalam kehidupannya lebih mengarah pada hal yang negatif dan mengenai cara bertahan hidup antar komunitas sesamanya. Hal tersebut tentu berbeda dengan kehidupan para waria yang menjadi santri di Pesantren Al-Fatah ini. Maka menjadi suatu hal yang menarik untuk dikaji lebih dalam lagi tentang kegiatan santri waria dalam lingkup keagamaan.

Berdasarkan pada hal-hal tersebut, maka perlu dilihat lebih mendalam lagi tentang pembinaan keagamaan yang dilaksanakan di Pesantren Al-Fatah, dan kehidupan santri waria dalam lingkup kegiatan keagamaan. Hal inilah yang akan diungkap dalam penelitian yang dilakukan peneliti. Oleh karena itu peneliti mengambil judul "PEMBINAAN KEAGAMAAN BAGI SANTRI WARIA DI PESANTREN AL-FATAH KOTAGEDE YOGYAKARTA".

\section{METODE}

Dalam penelitian ini, peneliti menggunakan pendekatan kualitatif, pendekatan kualitatif dapat diartikan penelitian yang menekankan pada quality atau hal yang terpenting dari sifat suatu barang atau jasa. Yang dimaksud hal terpenting dari suatu barang atau jasa berupa kejadian atau gejala sosial adalah makna dibalik kejadian tersebut yang dijadikan sebagai pelajaran berharga bagi suatu pengembangan konsep teori (Satori \& Komariah, 2013, hal. 22).

Penelitian ini menggunakan metode deskriptif. Metode deskriptif adalah data yang dikumpulkan berupa kata-kata, gambar dan bukan angka-angka. Selain itu, semua yang dikumpulkan berkemungkinan menjadi kunci terhadap apa yang sudah diteliti(Basrowi \& Suwandi, 2008, hal. 28).

Pesantren waria Al-Fatah Kotagede Yogyakarta ini terletak di Celenan RT 09/RW 02 Jagalan, Banguntapan (pos Kotagede), Bantul, Yogyakarta.

Di dalam penelitian ini, yang dimaksud dengan subjek adalah populasi. Dalam penelitian kualitatif tidak menggunakan istilah populasi, tetapi menurut Spradley dinamakan dengan situasi sosial yang terdiri dari tiga elemen, yaitu tempat, pelaku, dan aktivitas yang berinteraksi secara sinergis (Sugiyono, 2013, hal. 297).

Peneliti kualitatif sebagai human instrument, berfungsi menetapkan fokus penelitian, memilih informan sebagai sumber data, melakukan pengumpulan data, menilai kualitas data, analisis data, menafsirkan data dan membuat kesimpulan atas temuannya(Sugiyono, 2015, hal. 306). Adapun teknik pengumpulan data dilakukan dengan tiga cara yaitu: wawancara, observasi dan studi dokumentasi.

Adapun partisipan atau responden untuk wawancara diantaranya, melakukan wawancara dengan pimpinan pondok pesantren Al-Fatah, wawancara dengan pengurus pesantren waria, wawancara ustāż, wawancara dengan santri, dan wawancara dengan warga sekitar. Adapun teknik wawancara yang akan digunakan menggunakan metode terstruktur dan tidak terstruktur.peneliti menggunakan observasi sitematis dan berperan sebagai observasi partisipan agar dapat ikut serta dalam kegiatan yang ditelitinya. Akan tetapi, peneliti juga menggunakan observasi non partisipan yang bertujuan peneliti sebagai pengamat terhadap apa yang ditelitinya. 
Uji validitas dalam penelitian ini di lakukan beberapa hal, yaitu:

Triangulasi dapat diartikan sebagai teknik pengumpulan data yang bersifat menggabungkan dari beberapa teknik pengumpulan data dan sumber data yang telah ada. Ketika peneliti mengumpulkan data dengan triangulasi, maka peneliti mengumpulkan data sekaligus menguji kredibilitas/validitas data, yaitu kredibilitas dengan teknik pengumpuan data dan berbagai sumber data(Sugiyono, 2013, hal. 330).

Triangulasi teknik adalah menggunakan teknik pengumpulan yang berbeda-beda untuk mendapatkan data dari sumber yang sama. Peneliti menggunakan observasi partisipatif, wawancara mendalam dan dokumentasi untuk sumber data yang sama secara serempak. Dan triangulasi sumber yaitu untuk mendapatkan data dari sumber yang berbeda-beda dengan teknik yang sama (Sugiyono, 2013, hal. 330).

Peneliti menggunakan triangulasi teknik dan triangulasi sumber. Triangulasi teknik yaitu peneliti menguji validitas data dengan menyempurnakan yang sama dengan teknik yang berbeda, contohnya data yang diperoleh dari wawancara kemudian disempurnakan dengan observasi atau studi dokumentasi. Sedangkan, triangulasi sumber yaitu mencari data dari sumber yang berbeda yang masih terkait dengan pembinaan keagamaan bagi santri waria pada pesantren Al-Fatah melakukan dengan wawancara kepada pimpinan pesantren AlFataḥ, ustāż, dan pengurus pesantren waria.

Member check adalah proses pengecekan data yang diperoleh peneliti kepada pemberi data. Adapun tujuan dari member check adalah untuk mengetahui seberapa jauh data yang diperoleh sesuai dengan data yang di berikan oleh pemberi data. Apabila data yang di temukan di sepakati oleh pemberi data berarti data tersebut valid, dan semakin kredibel/ dipercaya(Sugiyono, 2013, hal. 375).
Data yang sudah diperoleh melalui teknik pengumpulan tersebut, langkah selanjutnya menganalisis data. Analisis data adalah proses mencari dan menyusun secara sistematis data yang diperoleh dari hasil wawancara, catatan lapangan, dan dokumentasi, dengan mengorganisir data ke dalam kategori(Sugiyono, 2015, hal. 335). Langkah pertama yang dilakukan dalam analisis data adalah mereduksi data dengan cara memilih data yang dibutuhkan serta dikategorikan dengan koding. Setelah itu data hasil reduksi lalu disajikan dalam display data dengan uraian singkat secara deskriptif dan setelah kedua tahap itu selesai selanjutnya adalah menyimpulkan apa yang telah disusun.

\section{HASIL DAN PEMBAHASAN}

1. Suatu perencanaan terdapat limahal pokok, yaitu (1) adanya tujuan yang hendak dicapai dari sesuatu yang direncanakan, (2) adanya rangkaian kegiatan yang tersusun sistematis untuk mencapai tujuan, (3) sumber daya manusia yang akan melaksanakan rencana yang disusun untuk mencapai tujuan, (4) penetapan waktu kapan rencana akan dilaksanakan, (5) penterjemahan rencana ke dalam program yang kongkrit dan nyata serta mudah diaplikasikan (Syah, 2007, hal. 29-30).

Membahas tentang perencanaan di Pesantren Waria Al-Fatah Kotagede Yogyakarta, dirasa perlu untuk membahas teori tentang pesantren pada umumnya. secara terminologis, pesantren didefinisikan sebagai lembaga pendidikan tradisional Islam untuk mempelajari, memahami, mendalami, menghayati, dan mengamalkan ajaran Islam dengan menekankan pentingnya moral keagamaan sebagai pedoman perilaku sehari-hari (Damopolii, 2011, hal. 57-58).

Pendapat lain menyebutkan pesantren adalah adalah suatu lembaga pendidikan agama Islam yang tumbuh serta diakui masyarakat sekitar, dengan sistem asrama (komplek) dimana santri- 
santri menerima pendidikan agama melalui sistem pengajian atau madrasah yang sepenuhnya berada di bawah kedaulatan dari leadership seorang atau beberapa orang kiai dengan ciri-ciri khas yang bersifat karismatik serta independen dalam segala hal (Qomar, 2010, hal. 2).

Setelah memaparkan teori tentang pesantren, dapat disimpulkan berdasarkan hasil observasi dan wawancara, bahwa pesantren waria ini tidak seperti pesantren pada umumnya. Pesantren waria ini memiliki persamaan dan perbedaan dari pesantren lainnya yang umumnya orang telah mengetahuinya. Persamaan di pesantren ini adalah sesuai dengan teori yang telah dituliskan di atas bahwa pesantren ini sebagai lembaga pendidikan tradisional Islam untuk mempelajari, memahami, mendalami, menghayati, dan mengamalkan ajaran Islam dengan menekankan pentingnya moral keagamaan sebagai pedoman perilaku sehari-hari.

Sedangkan perbedaannya adalah bahwa pesantren waria ini tidak memiliki asrama sebagai fasilitas santri, dan sistem pengajaran di pesantren waria ini tidak seperti pesantren pada umumnya yang menggunakan sistem madrasah yang pembinaannya dilakukan setiap hari dan setiap waktu sedangkan di pesantren waria ini pembinaan rutin dilaksanakan setiap seminggu sekali tepatnya hari minggu dan sebulan sekali tepatnya minggu ketiga yang diisi oleh pembina pesantren dari UNISNU. Dikarenakan santri waria ini harus menjalani rutinitas lainnya yakni bekerja untuk memenuhi kebutuhan sehari-hari.

Pembinaan keagamaan di pesantren waria yang rutinnya dilakukan hanya pada hari minggu ini tidak luput dari perencanaan yang matang. Keberhasilan dari suatu kegiatan dapat ditentukan oleh perencanaannya. Jika perencanaan suatu kegiatan dirancang dengan baik, maka kegiatan akan lebih mudah dilaksanakan dengan terarah dan terkendali. Demikian pula dengan perencanaan pembinaan keagamaan yang ada di Pesantren Waria Al-Fatah Kotagede Yogyakarta, agar pelaksanaan terlaksana dengan baik dan sesuai dengan tujuan yang diharapkan maka diperlukan perencanaan kegiatan yang telah dirancang dengan matang.

Perencanaan yang dilakukan, pada awalnya merujuk pada tujuan yang telah dipaparkan oleh ketua pesantren yakni memberikan ruang nyaman untuk beribadah bagi waria, serta mengadvokasi pemerintah tentang keberadaan waria dan keberagamaannya. Kemudian memberikan kemampuan dasar dan pengetahuan agama kepada para (santri) waria akan pentingnya nilai-nilai keagamaan.Meningkatkan dan mengembangkan kehidupan (santri) waria sebagai pribadi dan anggota masyarakat, dan mempersiapkan para (santri) waria untuk bergaul dan mengarungi kehidupan yang lebih bermanfaat dan bertanggung jawab.

Hasil dari perencanaan yang telah didiskusikan maka kegiatan di pesantren dibagi menjadi tiga bagian, yaitu:

a.

Kegiatan Rutin (Mingguan)

Kegiatan rutin ini yakni kajian mingguan yang diadakan setiap hari minggu dari pukul 16.00 sampai dengan 21.00. Kajian ini menjadi kegiatan utama di pesantren ini karena pembelajaran diadakan setiap hari minggu tersebut. Pertama ustāż membuka, setelah itu santri berkelompok untuk belajar Al-Qur'ān dan iqra' bagi yang belum bisa membaca Al-Qur'ān , kemudian shalat maghrib berjama'ah, do'a, shalawatan dan dzikir, shlat isyā berjama'ah, kajian keagamaan.

b. Kegiatan Bulanan

Kegiatan bulanan ini dilakukan setiap minggu ketiga. Kegiatan ini berupa kajian yang diisi oleh pembina langsung utusan dari UNISNU yakni K.H. Abdul Muhaimin. Kegiatan bulanan ini kegiatan khusus membahas tentang kedudukan waria dalam Islam.

c. Kegiatan Tahunan 
Kegiatan tahunan meliputi kegiatan hari-hari besar Islam seperti Maulid Nabī, Isra' Mi'raj. Selain hari-hari besar Islam juga ada selain hari besar Islam namun dilaksanakan setahun sekali yakni IDAHOT (International Day Againts Homo Phobia dan Transphobia). IDAHOT ini dimana hari yang menolak pada homo dan transphobia. Kemudian yang terakhir adalah memperingati hari transgender internasional.

Secara keseluruhan perencanaan pembinaan keagamaan di Pesantren Waria Al-Fatah Kotagede Yogyakarta telah sesuai, hal ini sejalan dengan pendapat Nanang Fattah (2009:49) perencanaan merupakan tindakan menetapkan terlebih dahulu apa yang akan dikerjakan, bagaimana cara mengerjakannya, apa yang harus dikerjakan, dan siapa yang mengerjakannya. Pesantren Waria AlFatah Kotagede Yogyakarta telah memenuhi kriteria dalam merencanakan suatu kegiatan berdasarkan penjelasan yang telah dipaparkan di atas. Kemudian Pesantren ini pun telah memiliki tujuan sebagai rujukan dalam perencanaan hal yang ingin dicapai adanya tujuan yang hendak dicapai, adanya rangkaian kegiatan yang telah tersusun untuk mencapai tujuan, ada sumber daya manusia yang akan melaksanakan rencana yang disusun untuk mencapai tujuan, telah ditetapkan waktu kapan rencana akan dilaksanakan.

2. Pelaksanaan pembinaan keagamaan di pesantren Al-Fatah Kotagede Yogyakarta.

Pembinaan keagamaan di Pesantren

Waria Al-Fatah Kotagede Yogyakarta meliputi perencanaan pembinaan, pelaksanaan pembinaan, dan hasil dari pembinaan. Perencanaan pembinaan keagamaan di Pesantren Al-Fatah Kotagede Yogyakarta telah dipaparkan dan dianalisis. Langkah kedua untuk mengimplementasikan rencana yang telah dirancang yakni pelaksanaan.

dalam manajemen adalah penempatan semua anggota atau kelompok agar bekerja secara sadar untuk mencapai tujuan yang telah ditetapkan sesuai dengan perencanaan yang telah disusun(Ramayulis, 2012, hal. 381).

Dalam pendidikan Islam pelaksanaan adalah untuk memberikan arahan, bimbingan, dan dorongan kepada seluruh sumber daya manusia dari personil yang ada dalam suatu organisasi agar dapat menjalankan tugas dengan kesadaran yang paling tinggi (Ramayulis, Ilmu Pendidikan Islam, 2008, hal. 274).

Pembinaan atau pengembangan adalah upaya pendidikan baik secara formal maupun non formal yang dilaksanakan secara sadar, terarah, teratur dan bertanggung jawab dalam rangka membimbing dan mengembangkan suatu dasar kepribadian yang seimbang, utuh dan selaras untuk mengembangkan dirinya kearah pribadi yang mandiri (Gafur, Pola Dasar Pembinaan dan Pengembangan Generasi Muda, 1978, hal. 7). Berdasarkan penjelasan ini, pelaksanaan kegiatan kajian yang dilakukan di Pesantren Waria Al-Fatah Kotagede Yogyakarta telah dilaksanakan secara terarah dan teratur. Hal ini telah dibuktikan pada program mingguan dan bulanan yang dilakukan sesuai jadwal yang telah ditetapkan dan terorganisir dengan baik, dari mulai persiapan hingga penutup.

Pada proses pembinaan ini ada tiga tahapan, yaitu kegiatan awal, kegiatan inti, dan kegiatan penutup. Pada kegiatan awal ustāż membuka dengan salam kemudian santri dan ustāż membaca basmallah bersama-sama, menanyakan tentang perkembangan akhlak dan ibadah seharihari.

Dalam kegiatan inti pada awalnya para santri duduk dikelompokkan menjadi lima kelompok, tiga kelompok yang sudah bisa membaca Al-Qur'ān dan dua kelompok belum bisa membaca Al-Qur'ān dan belajar iqra' yang dibimbing oleh ustāż yang bertanggung jawab pada kelompok masing-masing. Kemudian shalat maghrib berjama'ah, dilanjut dengan 
do'a bersama, shalawatan dan dzikir, kemudian shalat isyā berjama'ah, kemudian istirahat sejenak sambil ada pengumuman jika ada yang ingin diumumkan, kemudian mulai kajian keagamaan yang diisi oleh ustāż. Dilanjutkan dengan tanya jawab dan diskusi jika ada yang kurang paham soal materi atau ada yang ingin ditanyakan diluar materi hari ini namun masih tetap tentang keislaman.

Pada kegiatan penutup ustāż menanyakan apakah sudah paham atau belum jika ada yang belum paham maka ustāż mengulang penjelasannya kembali. Ustāż pun mempersilakan kembali jika ada santri yang masih ingin bertanya tentang materi yang telah disampaikan. Jika sudah tidak ada yang ditanyakan lagi oleh santri maka ustāż akan menyimpulkan materi yang telah disampaikan kemudian ditutup dengan membaca do'a akhir majlis dan hamdalah bersama-sama serta salam oleh ustāż.

Pembinaan, baik pengawasan maupun supervisi, dapat dilakukan dengan menggunakan pendekatan langsung (direct contect) dan pendekatan tidak langsung (indirect contect). Pendekatan langsung terjadi apabila pihak pembina melakukan pembinaan melalui tatap muka dengan yang dibina atau dengan pelaksana program. Pembinaan langsung ini dapat dilakukan melalui kegiatan diskusi, rapat, tanya jawab, kunjungan lapangan, kunjungan rumah, dan lain sebagainya. Sedangkan pembinaan tidak langsung terjadi apabila pihak yang membina melakukan upaya pembinaan kepada pihak yang dibina melalui media massa seperti melalui petunjuk tertulis, korespondensi, penyebaran bulletin, dan media elektronik seperti radio dan kaset (Sudjana, Evaluasi Program Pendidikan Luar Sekolah, 2010, hal. 218).

Adapun pembinaan keagamaan yang dilaksanakan di Pesantren Waria AlFatah Kotagede Yogyakarta yang telah dirancang oleh ketua, pengurus, para ustāż dan pembina lebih kepada menggunakan pembinaan langsung. Dimana dalam pendekatan langsung pihak pembina/ustāż melakukan pembinaan melalui tatap muka langsung dengan para pihak yang dibina, contohnya pada kegiatan kajian keagamaan yang menjadi kegiatan utama dan rutin dilakukan setiap hari minggu sore sampai malam bertempat di kediaman Sinta Ratri, dan kegiatan bulanan yang dilakukan pada minggu ketiga dengan pemateri pembina pesantren dari UNISNU.

Dengan demikian pembinaan merupakan satu kegiatan yang memiliki tujuan, proses, dan hasil yang ingin dicapai baik melalui pendekatan langsung ataupun pendekatan tidak langsung. Sebagaimana yang telah dipaparkan di atas bahwa pendekatan yang dilakukan di Pesantren Waria Al-Fatah Kotagede Yogyakarta yakni pendekatan langsung yang mana pendekatan ini dianggap paling efektif digunakan karena menghasilkan suatu perubahan perilaku yang besar dan lebih mudah dilaksanakan oleh para pembina. Pendekatan langsung selain digunakan oleh ustāż juga dibutuhkan oleh para santri sebagai alat untuk lebih dekat dengan para ustāż sehingga dapat menerima materi dan pembelajaran dengan lebih mudah dan nyaman.

Adapun materi kajian pembinaan keagamaan yang ada di Pesantren Waria Al-Fata Kotagede Yogyakarta berdasarkan hasil observasi diantaranya yaitu, pertama akhlak, kedua aqīiah, ketiga ibadah, keempat baca tulis Al-Qur`ān beserta tajwidnya.

Materi-materi yang terdapat dan diberikan kepada santri waria di Pesantren Al-Fatah Kotagede Yogyakarta ini akan lebih mudah diterima oleh santri dan lebih mudah dilakukan oleh ustāż apabila menggunakan metode-metode yang sesuai.

Metode dapat diartikan sebagai alat yang digunakan dalam proses pencapaian tujuan, alat tersebut dapat efektif bila penggunaannya disesuaikan dengan fungsi alat tersebut. Dalam pengertian yang sederhana metode adalah suatu cara untuk menyampaikan suatu nilai tertentu dari si 
pembawa pesan kepada si penerima pesan, dalam konteks pendidikan, si pembawa pesan adalah guru dan si penerima pesan adalah murid. Metode juga diartikan sebagai salah satu komponen penting yang menghubungkan tindakan dengan tujuan pendidikan, sebab tidak mungkin materi pendidikan dapat diterima dengan baik kecuali disampaikan dengan metode yang tepat (Syahidin, 2009, hal. 43).

Adapun metode-metode yang digunakan dalam pembinaan keagamaan di Pesantren Waria Al-Fatah Kotagede Yogyakarta yaitu, metode ceramah, metode tanya jawab, dan metode diskusi.

Setelah metode pembinaan keagamaan pun membutuhkan media. Media yang digunakan untuk mengajar adalah papan tulis, buku tulis, dan sumber ajar.

Pelaksanaan pembinaan bukan suatu hal yang mudah untuk dilaksanakan, dalam pelaksanaannya pasti ada hambatan dan rintangan yang membuat tidak mulus jalannya pelaksanaan pembinaan keagamaan. Di pesantren ini memiliki beberapa hambatan yang terjadi, yaitu: 1) beban ekonomi, seringkali santri tidak hadir karena harus bekerja untuk memenuhi kebutuhan sehari-hari. 2) rumah santri sangat jauh dari pesantren sehingga waktu pembinaan ini terbatas. 3) kendala yang dirasakan oleh ustāż selama pembinaan yaitu keterbatasan fasilitas di pesantren. 4) kendala terakhir yang dirasakan adalah santri yang belajar di pesantren ini mudah lupa materi.

Secara keseluruhan dapat
disimpulkan bahwa pelaksanaan
pembinaan keagamaan di Pesantren Waria Al-Fatah Kotagede Yogyakarta telah berjalan dengan baik serta sesuai dengan perencanaan yang telah direncanakan. Terlihat dengan adanya jadwal-jadwal kegiatan yang terimplementasi dalam pelaksanaan sebagaimana observasi yang telah dilakukan dalam setiap kegiatankegiatannya.
3. Hasil pembinaan keagamaan bagi santri waria di Pesantren Al-Fatah Kotagede Yogyakarta.

Hasil dari pembinaan keagamaan bagi santri waria di Pesantren Al-Fatah Kotagede Yogyakarta ini kembali kepada tujuannya didirikannya pesantren ini, yaitu memberikan ruang nyaman untuk beribadah bagi waria, mendidik masyarakat tentang hak beribadah pada waria, kemudian untuk memberikan kemampuan dasar dan pengetahuan agama kepada para santri waria akan pentingnya nilai-nilai keagamaan, serta meningkatkan dan mengembangkan kehidupan santri waria sebagai pribadi dan anggota masyarakat, dan mempersiapkan para santri waria untuk bergaul dan mengarungi kehidupan yang lebih bermanfaat dan bertanggung jawab.

Maka dari itu kajian rutin pembinaan keagamaan wajib diberikan kepada para santri tujuannya untuk membina akhlak mereka agar mereka dapat menjalankan segala perintah Allah Swt., dan menjauhi larangan Allah Swt. Kesimpulan yang dapat di ambil bahwa target dari pembinaan keagamaan itu bukan sekedar hanya pemberian pengetahuan saja melainkan ada hal yang lebih penting yakni membina atau mengajarkan segala hal yang berhubungan dengan ibadah.

Hasil dari penelitian kegiatan pembinaan keagamaan di Pesantren Waria Al-Fatạ Kotagede Yogyakarta menggunakan dua cara, yaitu dalam bentuk observasi langsung setiap kegiatan dan wawancara langsung kepada ketua, pengurus, ustāż, santri dan warga sekitar. Berdasarkan hasil wawancara dengan beberapa santri dan pengurus dapat disimpulkan bahwa tingkat keberhasilan diadakannya pembinaan keagamaan di Pesantren Waria Al-Fatah Kotagede Yogyakarta dapat dikatakan berhasil dengan hasil yang cukup baik.Keberhasilan ini dilihat dari banyaknya perubahan yang terlihat seperti lebih bisa menahan amarahnya, rajin 
shalat, bersemangat untuk belajar agama serta melaksanakannya, bahkan ada yang sampai berhenti nyebong (pekerja seks) karena sudah ingin taubat dari perbuatan terlaknat tersebut. Masyarakat sekitar pun dapat menerima dengan baik kehadiran waria di lingkungan tersebut tidak merasa terganggu bahkan cenderung akur.

Santri di pesantren ini tidak hanya sekedar dilihat dari perubahan dalam diri saja, namun juga dilihat dari penghasilan yang didapat pun sudah berubah. Sebelum menjadi santri di pesantren ini para waria banyaknya bekerja sebagai pekerja seks yang tidak halal, namun setelah dibina dan diberi kajian keagamaan serta diajarkan membaca Al-Qur'ān beserta maknanya mereka kebanyakan beralih profesi dan mencari penghasilan dengan cara yang halal.

Dampak itu sesuatu yang pasti ada dalam setiap kegiatan yang dilakukan, begitupun dengan keberadaan pesantren waria beserta kegiatan yang dilakukan dalam Pesantren Waria Al-Fatah Kotagede Yogyakarta. Adanya pesantren waria terutama ketua pesantren Sinta Ratri yang memang warga disana sangat berdampak pada warga sekitar. Jika ada pengajian maka warga sekitar pun turut diundang dalam pengajian tersebut. Warga disekitar pesantren waria ini tidak pernah mengadakan acara apapun yang berarti hanya arisan ibu-ibu atau arisan bapakbapak, namun setelah adanya pesantren waria warga sekitar menjadi ada kegiatan antar warga, seperti acara tujuh belas agustusan, syawalan, pengajian. Warga jadi sering membantu Pesantren Al-Fatah jika ingin diadakan acara. Ibu-ibu membantu memasak sedangkan bapakbapak membantu memasang tenda. Sangat berdampak baik adanya pesantren waria di kalangan warga sekitar dan diri waria sendiri.

Evaluasi yang dilakukan di pesantren waria ini tidak secara formal melainkan non formal. Evaluasinya pun tidak secara tertulis seperti pesantrenpesantren pada umumnya. Evaluasi ini juga ada yang dilakukan pada setiap tahunnya, evaluasi ini dikaitkan dengan perlombaan-perlombaan tentang pelajaran agama yang telah dipelajari dan dilakukan pada bulan ramadhan yang diikuti oleh para santri. Santri tidak sadar bahwa perlombaan ini adalah salah satu bentuk evaluasi yang dinilai oleh ustāż apakah mereka masih ingat materi yang telah disampaikan dan dijelaskan atau tidak. Dan yang menang mendapat hadiah juga nilai tambahan dari ustāż.

Menurut Arifin (dalam Nasih \& Kholidah, 2013, hal. 158) evaluasi pendidikan Islam sebagai cara atau teknik penilaian terhadap tingkah- laku anak didik berdasarkan perhitungan yang komprehensif dari seluruh aspek kehidupan mental psikologis dan spiritualreligius. Teknik ini didasarkan pada pertimbangan bahwa manusia adalah pribadi yang tidak hanya bersifat religius, melainkan juga berilmu dan berketerampilan yang sanggup beramal dan taat kepada Tuhan dan masyarakatnya.

Evaluasi atau penilaian dapat diselenggarakan secara terus menerus, berkala dan sewaktu-waktu pada saat sebelum, sedang atau setelah program pendidikan dilaksanakan. Penilaian juga dirasa kegiatan yang penting untuk mengetahui apakah tujuan yang telah ditentukan dapat dicapai atau tidak, kemudian apakah pelaksanaan sesuai dengan rencana yang telah dirancang atau tidak, serta apa dampak yang terjadi setelah program dilaksanakan (Sudjana, 1992, hal. 241).

\section{KESIMPULAN}

Berdasarkan dari hasil penelitian dan pembahasan yang telah dipaparkan di atas, maka dapat disimpulkan bahwa secara keseluruhan pembinaan keagamaan di Pesantren Waria Al-FatahKKotagede Yogyakarta sudah cukup baik, dilihat dari perencanaan, pelaksanaan dan hasil pembinaan keagamaan. Namun, evaluasi di Pesantren WariaAl-Fatah Kotagede 
Yogyakarta ini belum cukup baik dikarenakan pesantren ini tidak seperti pesantren pada umumnya yang tertulis secara terstruktur dan pesantren ini termasuk ke dalam pembinaan informal yang tidak terikat oleh apapun serta memiliki kebebasan untuk mengembangkan diri sendiri.

Secara khusus kesimpulan yang diambil dari hasil pengolahan data penelitian dan analisis data penelitian mencakup (1) Perencanaan pembinaan keagamaan bagi santri waria di Pesantren Al-Fatah Kotagede Yogyakarta; (2) Pelaksanaan pembinaan keagamaan bagi santri waria di Pesantren Al-Fatah Kotagede Yogyakarta; (3) Hasil pembinaan keagamaan bagi santri waria di Pesantren Al-Fatah Kotagede Yogyakarta. Ukuran keberhasilan pembinaan keagamaan bagi santri waria di Pesantren Al-Fatah Kotagede Yogyakarta ini dilihat dari tujuan serta visi dan misi pada pesantren, seberapa tercapainya tujuan serta visi misi yang ada di pesantren ini. Mereka merasa nyaman bergabung di PesantrenWariaAl-Fatah, mereka pun merasa tambah wawasannya setelah diberi materi kajian oleh ustāż, serta merasa diri lebih baik dari sebelum bergabung ke pesantren waria ini, seperti contohnya dapat menahan amarah yang sebelumnya jika marah akan meledak-ledak. Sudah bisa beribadah dengan tenang dan tata cara yang baik dan benar setelah diberikan pembelajaran. Banyak perubahan di dalam diri terutama masalah pekerjaan yang tadinya pekerjaan haram menjadi pekerjaan halal.

\section{REFERENSI}

Arifin, M. (1976). Pokok-Pokok Pikiran Tentang Bimbingan dan Penyuluhan Agama. Jakarta: Bulan Bintang.

Arifin, M. (1982). Pedoman Pelaksanaan Bimbingan dan Penyuluhan Agama. Jakarta: Golden Terayon.

Basrowi, \& Suwandi. (2008). Memahami Penelitian Kualitatif . Jakarta: Rineka Cipta .

Damopolii, M. (2011). Pesantren Modern IMMIM: Pencetak Muslim Modern. Jakarta: Rajawali Pers.

Darajat, Z. (1982). Pendidikan Agama dalam Pembinaan Mental. Jakarta: Bulan Bintang.

Fattah, N. (2009). Landasan Manajemen Pendidikan. Bandung: Remaja Rosda Karya.

Gafur, A. (1978). Pola Dasar Pembinaan dan Pengembangan Generasi Muda. Jakarta: Sekretariat Menteri Muda Urusan Pemuda Departemen Pendidikan dan Kebudayaan.

Jevuska. (2012, September 30). Artikel kedokteran, Blog, Sosial Media, Tutorial, dan Berita. Dipetik Juni 6, 2014, dari Definisi Transgender, Asal usul, dan Perubahan Gender: http://www.jevuska.com/2012/09/3 0/perubahan-gender-asal-usul-dandefinisi-transgender/

Juwandi. (2009). Makna Agama dalam Perspektif Hidup Waria pada Komunitas Pengajian Hadrah AlBanjari Waria Al-Ikhlas Surabaya. FPSI Universitas Mercubuana Yogyakarta.

Mastuhu. (1994). Dinamika Sistem Pendidikan Pesantren: Suatu Kajian Tentang Unsur dan Nilai Sistem Pendidikan Pesantren. Jakarta: INIS. 
Mujid, A., \& Mudzakkir, J. (2008). Ilmu Pendidikan Islam. Jakarta: Kencana.

Nasih, A. M., \& Kholidah, L. N. (2013). Metode dan Teknik Pembelajaran Pendidikan Agama Islam. Bandung: Refika Aditama.

Qomar, M. (2010). Pesantren Dari Transformasi Metodologi Menuju Demokratisasi Institusi. Jakarta: Erlanggga.

Rahmawati, A. (2001). Pembinaan bagi Tunanetra di YAKETUNIS. Yogyakarta: Skripsi Institut Agama Islam Negeri Sunan Kalijaga Yogyakarta.

Ramayulis. (2008). Ilmu Pendidikan Islam. Jakarta: Kalam Mulia.

Ramayulis. (2012). Ilmu Pendidikan Islam. Jakarta: Kalam Mulia.

Rif'ani, N. K. (2015). Dahsyatnya Mendidik Anak Gaya Rasulullah. Yogyakarta: Semesta Hikmah.

Satori, D., \& Komariah, A. (2013). Metodelogi Penelitian Kualitatif. Bandung: Alfabeta.

Stavia, J. (2013, Juni Minggu). Psikologi Universitas Bunda Mulia. Dipetik Juni Kamis, 2014, dari

Transgender:

http://psikologiubm.blogspot.com/2

013/06/transgender.html

Sudjana. (1992). Pengantar Manajemen Pendidikan Luar Sekolah. Bandung: Nusantara Press.

Sudjana. (2010). Evaluasi Program Pendidikan Luar Sekolah. Bandung: Remaja Rosda Karya.

Sugiyono. (2013). Metode Penelitian Pendidikan. Bandung: Alfabeta.

Sugiyono. (2015). Metode Penelitian Pendidikan Pendekatan Kuantitatif, Kualitatif, dan $R \& D$. Bandung: Alfabeta.
Syah, D. (2007). Perencanaan Sistem Pengajaran Pendidikan Agama Islam. Jakarta: Gaung Persada Press.

Syahidin. (2009). Menelusuri Metode Pendidikan Dalam Al-Quran. Bandung: Alfabetha.

Tafsir, A. (2012). Ilmu Pendidikan Islami. Bandung: Remaja Rosdakarya.

Yash. (2003). Transseksualisme (Sebuah Studi Kasus Perkembangan Transseksual Perempuan ke LakiLaki. Semarang: Penerbit AINI. 